\title{
Chemical and Physical Quality Criteria of Bulakbaşı Stream in Turkey and Usage of Drinking, Fisheries, and Irrigation
}

\author{
Fazıl Şen and Abdullah Aksoy \\ Faculty of Fisheries, Department of Basic Sciences, Yüzüncü Yıl University, Tuşba, 65080 Van, Turkey \\ Correspondence should be addressed to Fazıl Şen; fazilsen1@gmail.com
}

Received 3 March 2015; Accepted 4 June 2015

Academic Editor: Ana Moldes

Copyright ( 2015 F. Şen and A. Aksoy. This is an open access article distributed under the Creative Commons Attribution License, which permits unrestricted use, distribution, and reproduction in any medium, provided the original work is properly cited.

\begin{abstract}
Water quality parameters were analyzed in Bulakbaşı stream. The in situ measurements and laboratory analyses were made on water samples taken from 4 sampling points on the Bulakbașı stream monthly. During the study, the average water temperature as $16.3^{\circ} \mathrm{C}$, dissolved oxygen (DO) $12.91 \mathrm{mg} / \mathrm{L}$, oxygen saturation (OS) $152.8 \%, \mathrm{pH} 8.25$, electrical conductivity (EC) $779.6 \mu \mathrm{S} / \mathrm{cm}$, salinity $0.435 \%$, chloride $83.97 \mathrm{mg} / \mathrm{L}$, calcium $56.5 \mathrm{mg} / \mathrm{L}$, magnesium $57.1 \mathrm{mg} / \mathrm{L}$, total hardness $391.1 \mathrm{mg} / \mathrm{L} \mathrm{CaCO}$, carbonate $0 \mathrm{mg} / \mathrm{L}$, bicarbonate $365.95 \mathrm{mg} / \mathrm{L}$, total alkalinity $299.85 \mathrm{mg} / \mathrm{L}$, nitrate $4.74 \mathrm{mg} / \mathrm{L}$, nitrite $20.83 \mu \mathrm{g} / \mathrm{L}$, ammonium $50.8 \mu \mathrm{g} / \mathrm{L}$, ammonia $48.3 \mu \mathrm{g} / \mathrm{L}$, phosphorus $77.5 \mu \mathrm{g} / \mathrm{L}$, sulfate $57.6 \mathrm{mg} / \mathrm{L}$, potassium $4.52 \mathrm{mg} / \mathrm{L}$, copper and aluminum $0.0 \mu \mathrm{g} / \mathrm{L}$, total iron $10.1 \mu \mathrm{g} / \mathrm{L}$, zinc $168.2 \mu \mathrm{g} / \mathrm{L}$, chromium $24 \mu \mathrm{g} / \mathrm{L}$, manganese $401.7 \mu \mathrm{g} / \mathrm{L}$, and cyanide $6.79 \mu \mathrm{g} / \mathrm{L}$ were found. According to EU, WHO, and Turkish standards, Bulakbaşı stream is not polluted and it has suitable quality with respect to drinking, aquaculture, and irrigation.
\end{abstract}

\section{Introduction}

Water is an indispensible substance to be utilized for the survival of all biological organisms. Moreover, water is an essential requirement of human life and activities associated with industry, agriculture, fisheries, and others, and it is considered one of the most delicate parts of the environment [1]. For centuries, people have chosen to settle in areas which have been rich in water and eked out their living nearby water resources where they can use from plenty of water, or in which aquatic resources can easily and abundantly be obtained. However, the perturbations in the hydrodynamics in the earth's ecosystems and the population increases have imposed strains and stresses on water resources over time in these areas and necessitated water bodies to be constructed in order to have an adequate utilization and management of water resources. Furthermore, the amount of water in the world is limited, and it is a known fact that water can never be replaced with any other element in nature. The required quantity and quality of water resources in any given region are limited. Various factors are believed to contribute to a degradation and slump in water resources. For aquatic ecosystems, pollution is on of the most important problems nowadays; therefore, aquatic resources must be protected very well [2].

In meeting the energy needs, and of all natural resources, streams are considered to provide cheap, clean, and continuous supplies for biological species. It is therefore imperative to establish an appropriate regulatory system for the management and utilization of water resources. The potential of herbal production, flora, and fauna in any given area is proportionate to the potential of water resources to be utilized there. Facilities established for transportation, tourism, and recreation activities in any region also depend upon a healthy and effective management of water resources. It would therefore be of paramount significance for human beings eking out their livings in the local and natural environment to have an effective management of the water resources and protect the ecosystems of biological species in any given region on earth. In the biological richness of valuable fish stocks, there can be found numerous favors and utilities for humanity. In order to take due advantages and benefits from the rivers in the most effective way, their natural potential, physical wealth should be protected to ensure continuity and sustainability of their ecosystems; due examinations and analyses to be conducted about their chemical and biological properties are 


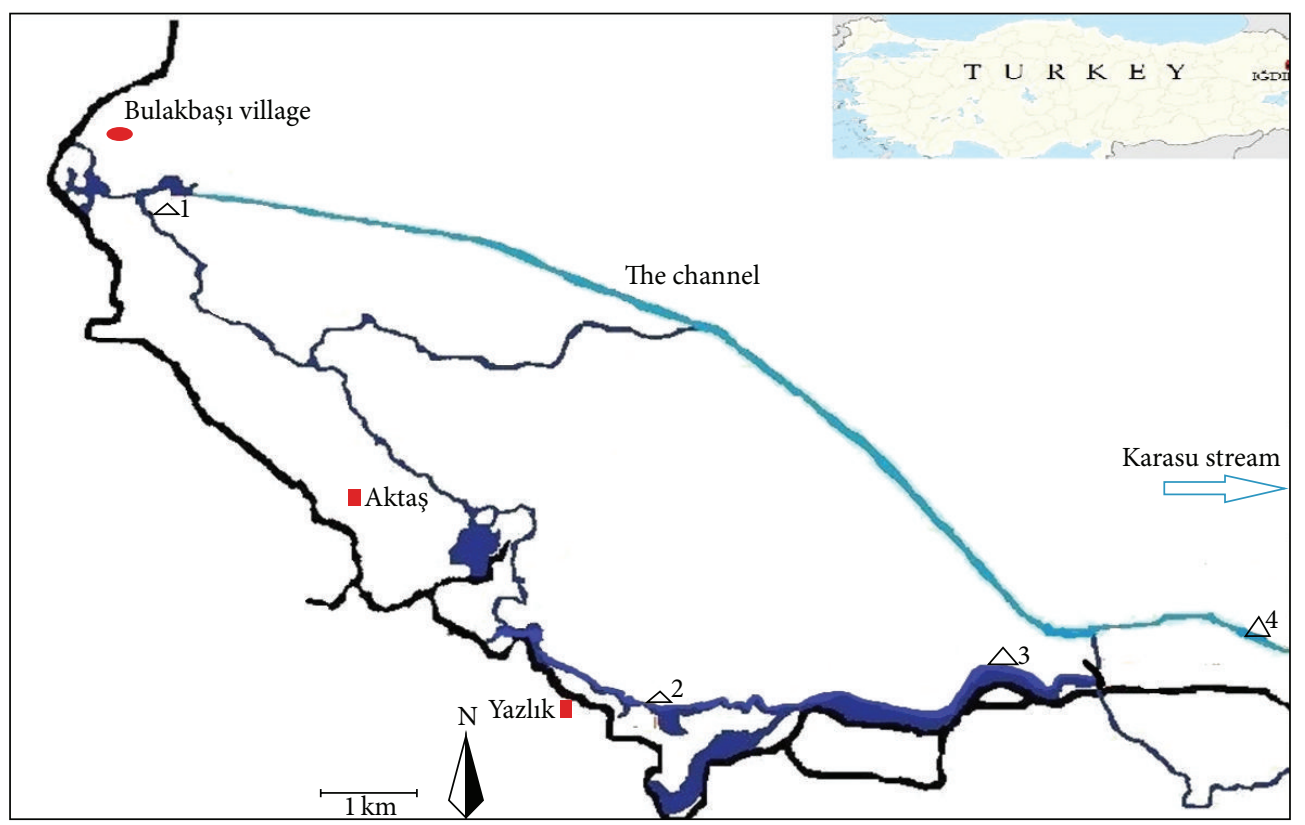

FIgURE 1: Bulakbaşı stream and four sampling points.

also of great value in order to have adequate utilization and management of these resources [3]. However, in recent years, decreases in the amount of potable water have prompted authorities to have much more effective management and control; it has become indispensable for them to take due measures [4].

No study has been conducted on the limnological features, water quality, and pollution of Bulakbaşı water so far. In this study, the current situation of Bulakbaşı, water quality criteria, and basic pollution parameters were discussed within the context of the aforementioned points and premises. Bulakbaşı stream was also investigated and analyzed for its properties of drinking, fisheries, and irrigation and recommendations were made for prospective researchers and authorities to conduct further studies on this stream.

\section{Materials and Methods}

Bulakbaşı stream is in eastern Turkey, within the domains of Iğdır province, intersecting with the borders of Armenia and Iran, in the foothills of Mount Ararat and within $39^{\circ}$ $56^{\prime} \mathrm{N}$ and $44^{\circ} 15^{\prime} \mathrm{E}$ coordinates. The altitude is between 820 and $850 \mathrm{~m}$, average annual temperature is $12^{\circ} \mathrm{C}$, and rainfall is about $255.2 \mathrm{~mm}$ around the area where the stream is scattered into mountainous terrain. The resources of this stream are within boundaries of Bulakbaşı, Aktaş, and Yazlık villages which are foothills of Mount Ararat. A regulator and irrigation channels have been constructed alongside the stream. Remaining water is poured into the Aras River using in this channel which is about $65 \mathrm{~km}$ far away (Figure 1). Around the terrain are large pastures [5].

Four sampling points, which were considered to be likely changed in water quality, have been determined to collect water samples and to make in situ measurements from Bulakbaşı stream (Figure 1). Research was carried out between October 2011 and September 2012. Examples were taken 15-20th days of each month at 12:00-15:00 hours. Water temperature, $\mathrm{pH}, \mathrm{EC}, \mathrm{DO}$, OS (\%), and salinity (\%o) were determined through the measurements conducted in the field of investigation with HACH-LANGE HQ40D multimeter. After the in situ measurements, the samples were taken in a volume of $1.5 \mathrm{~L}$ bottle, and we brought them to our laboratory, and then analyses were performed in replicates of two or three.

Calcium, magnesium, and total hardness were analyzed with EDTA method, chloride with Argentinometry (MohrKnudsen) method, and alkalinity and carbonate-bicarbonate $\mathrm{HCl}$ titration methods [6]. Aluminum with aluminon method (Hach method 8012), ammonia with Nessler method (Hach method 8038), copper with porphyrin method (Hach method 8143), zinc with zincon method (Hach method 8009), phosphorus with PhosVer 3-ascorbic acid method (Hach method 8048), chromium-hexavalent with 1.5-diphenylcarbohydrazide method (Hach method 8023), manganese with periodate oxidation method (Hach method 8034), nitrate with cadmium reduction method (Hach method 8039), nitrite with diazotization method (Hach method 8507), potassium with tetraphenylborate method (Hach method 8049), cyanide with pyridine-pyrazolone method (Hach method 8027), sulfate with SulfaVer 4 method (Hach method 8051), and total iron with TPTZ method (Hach method 8112) were analyzed with Hach-Lange DR 5000 spectrophotometer [6, 7]. Evaluation of the results and analysis was made with Turkish Standards (TS 266) [8]; Water Intended for Human Consumption Regulation (WHCR) [9], Water Pollution Control Regulation (WPCR) [10], World Health Organization (WHO), the European Union (EU) drinking (76/464/EEC) 
TABLE 1: Bulakbaşı water results obtained based on in situ measurements.

\begin{tabular}{|c|c|c|c|c|c|c|}
\hline Sampling months & Temperature $\left({ }^{\circ} \mathrm{C}\right)$ & $\mathrm{DO}(\mathrm{mg} / \mathrm{L})$ & OS (\%) & $\mathrm{pH}$ & $\mathrm{EC}(\mu \mathrm{S} / \mathrm{cm})$ & Salinity (\%o) \\
\hline October 2011 & 16.8 & 16.19 & 186.1 & 7.97 & 599.0 & 0.40 \\
\hline November 2011 & 16.6 & 15.71 & 180.4 & 7.99 & 576.0 & 0.40 \\
\hline December 2011 & 15.2 & 13.72 & 164.3 & 8.31 & 653.3 & 0.37 \\
\hline January 2012 & 14.5 & 12.12 & 142.3 & 8.27 & 661.3 & 0.38 \\
\hline February 2012 & 13.7 & 9.65 & 105.0 & 8.47 & 687.0 & 0.44 \\
\hline March 2012 & 12.7 & 11.46 & 118.1 & 8.83 & 664.8 & 0.43 \\
\hline April 2012 & 16.1 & 10.52 & 117.8 & 8.47 & 714.5 & 0.43 \\
\hline May 2012 & 17.5 & 13.93 & 162.2 & 8.35 & 1044.3 & 0.53 \\
\hline June 2012 & 19.7 & 11.21 & 163.5 & 8.23 & 941.5 & 0.48 \\
\hline July 2012 & 17.6 & 9.32 & 119.0 & 8.11 & 946.0 & 0.48 \\
\hline August 2012 & 17.8 & 14.42 & 181.3 & 7.85 & 930.0 & 0.43 \\
\hline September 2012 & 17.3 & 16.67 & 193.9 & 8.11 & 937.3 & 0.45 \\
\hline Mean & $16.3 \pm 1.97$ & $12.91 \pm 2.55$ & $152.8 \pm 31.15$ & $8.25 \pm 0.27$ & $779.6 \pm 165.55$ & $0.435 \pm 0.045$ \\
\hline
\end{tabular}

and fisheries (78/659/EEC) water directives [11], and other relevant legal and technical regulations have been made within a scientific framework [12]. Evaluation of the resulting data was made according to general statistical basis.

\section{Results and Discussion}

Due to the channel and regulator on the Bulakbaşı stream source, the original bottom and coastal structures degraded. Throughout the study, in the stream, freezing has not been observed. Slope along the river is low; the bottom is sandy and muddy. In the downside, a slight turbidity of the water can be observed.

Water temperature, $\mathrm{DO}, \mathrm{OS}, \mathrm{pH}, \mathrm{EC}$, and salinity values have been recorded through in situ measurements in the field, which are given in Table 1 according to the average of the months.

Temperature is important in the nutrition, reproduction, growth, and migration of fish and other aquatic organisms. Temperature changes will affect parameters such as $\mathrm{pH}$, EC, and DO [12]. Water temperature also directly affects the metabolism and physiology of aquatic organisms. Also temperature has an impact on the speed of the chemical reaction, the solubility of the gases, the taste, smell, and other properties of the water [11]. Temperature of drinking water has a direct association with the taste. Optimum drinking temperature is considered to be $10-12^{\circ} \mathrm{C}$ [13]. In this study, the average annual water temperature was defined as $16.3^{\circ} \mathrm{C}$, and the samples may be included in the first class according to [8-10] and $\mathrm{WHO}$ and EU drinking and fisheries directive [11]. The average values throughout the year never exceed $20^{\circ} \mathrm{C}$. Upper regions are suitable for trout aquaculture, and subregions for carp aquaculture [14]. Temperature values have been reported to be in Nazik Lake $2-24.5^{\circ} \mathrm{C}$ [15], in Akköprü stream $-1.0-24.5^{\circ} \mathrm{C}$ [16], and in Karasu Stream 0.8$24.5^{\circ} \mathrm{C}$ [17]. These values are similar to those found in our study.

The DO is one of the most important criteria for water quality control. Oxygen-saturated water has a good taste and the absence of water gives an insipid taste. Therefore, if there is a DO problem in drinking water, it should be ventilated [11]. The amount of DO in water is an indicator of the level of the water supply which is generally healthy [12]. DO value of this study was $12.91 \mathrm{mg} / \mathrm{L}$ and OS was $152.80 \%$. DO and OS values, in Akköprü stream $8.2 \mathrm{mg} / \mathrm{L}$ and $98.8 \%$ [16], in Karasu stream $10.03 \mathrm{mg} / \mathrm{L}$ and 119.4\% [17], in Nazik Lake from 1.0 to $13.2 \mathrm{mg} / \mathrm{L}$ [15], in Sakegaon River $6.5-8.2 \mathrm{mg} / \mathrm{L}$ [18], in Yuvarlakçay stream 5.5-14.4 mg/L [19], in Kelkit stream 7.68-9.90 mg/L [20], in Bhavani River 6.56-12.0 mg/L [21], in Sarada River 7.0-7.8 mg/L [22], in El-Kabir River 7.1 mg/L [23], in Cauvery River 1.34-5.5 mg/L [24], in Kosi River 6.2$6.8 \mathrm{mg} / \mathrm{L}$ [25], in Semenyih River 4.18-7.44 [1], and in Nainital Lake $5.77-8.2 \mathrm{mg} / \mathrm{L}$ [26], were reported. Bulakbaş1 stream is in the first-class water with regard to WPRC [10]. In trout farming, the DO should also be higher than $7 \mathrm{mg} / \mathrm{L}$ [14]. In first-class drinking water, OS in the EU directives must be $70 \%$ and above [11].

The $\mathrm{pH}$ of water plays an important role in the reproduction, growth, and nutrition. The higher the $\mathrm{pH}$ increases, the toxic the effect of ammonia is [12]. In waters, various chemical reactions are controlled by $\mathrm{pH}$. A vast majority of biological activities are restricted within a narrow range between $\mathrm{pHs} 5$ and 8 . Highly acidic or alkaline water is undesirable because of corrosion problems [11]. Optimum limit of $\mathrm{pH}$ for aquatic life is between 6.5 and $9.0[4]$. In $[8,9]$, the optimum $\mathrm{pH}$ range for first-class drinking water is between 6.5 and 9.5 , and in [10] and EU directive it is between 6.5 and 8.5 [11]. For aquaculture, the $\mathrm{pH}$ values between 6.5 and 8.5 [14] and, in EU fisheries directive, between 6 and 9 [11] were adopted. The average $\mathrm{pH}$ was determined as 8.25 in Bulakbaşı. The $\mathrm{pH}$ obtained from the study is suitable for general aquaculture. $\mathrm{pH}$ values are between 8.06 and 8.87 in [15], 7.19 and 7.32 in [18], 5.34 and 8.96 in [19], 7.76 and 8.45 in [20], 7.66 and 8.58 in [21], 7.85 and 8.0 in [22], 7.2 and 8.14 in [27], 7.3 and 7.9 in [25], 5.23 and 8.41 in [1], and 7.55 and 7.75 in [26], and an average of 7.98 in [23], 8.3 in [16], and 8.2 in [17] have been reported.

The EC of water source is connected with chemical structure of the stream bed and joins the speed and level of hydrocycle [12]. EC increase in drinking water is an indicator 
TABLE 2: Data obtained from titrimetric analysis conducted on Bulakbaşı water.

\begin{tabular}{|c|c|c|c|c|c|c|}
\hline Sampling months & $\mathrm{Cl}(\mathrm{mg} / \mathrm{L})$ & $\mathrm{Ca}(\mathrm{mg} / \mathrm{L})$ & $\mathrm{Mg}(\mathrm{mg} / \mathrm{L})$ & Hardness (mg/L) & $\mathrm{HCO}_{3}(\mathrm{mg} / \mathrm{L})$ & Alkalinity $(\mathrm{mg} / \mathrm{L})$ \\
\hline October 2011 & 80.9 & 59.2 & 67.2 & 497 & 359.0 & 294.25 \\
\hline November 2011 & 84.9 & 54.2 & 77.0 & 452 & 373.6 & 305.00 \\
\hline December 2011 & 95.7 & 65.2 & 83.8 & 533 & 358.9 & 294.13 \\
\hline January 2012 & 85.9 & 67.5 & 62.3 & 479 & 349.8 & 286.75 \\
\hline February 2012 & 74.4 & 47.5 & 55.5 & 377 & 369.7 & 303.00 \\
\hline March 2012 & 79.9 & 47.5 & 46.0 & 308 & 404.1 & 331.25 \\
\hline April 2012 & 77.8 & 50.5 & 56.0 & 357 & 403.7 & 330.88 \\
\hline May 2012 & 91.7 & 48.6 & 48.4 & 320 & 358.1 & 293.50 \\
\hline June 2012 & 80.5 & 45.6 & 54.8 & 339 & 347.9 & 285.13 \\
\hline July 2012 & 80.5 & 47.8 & 44.4 & 302 & 354.9 & 290.88 \\
\hline August 2012 & 88.2 & 73.3 & 47.9 & 380 & 356.4 & 292.13 \\
\hline September 2012 & 87.7 & 70.6 & 41.9 & 349 & 355.3 & 291.25 \\
\hline Mean & $83.97 \pm 6.12$ & $56.5 \pm 10.2$ & $57.1 \pm 13.2$ & $391.1 \pm 79.0$ & $365.95 \pm 19.13$ & $299.85 \pm 15.64$ \\
\hline
\end{tabular}

of pollution or mixing of the sea water [13]. The mean EC in Bulakbaşı was defined as $779.6 \mu \mathrm{S} / \mathrm{cm}$. EC values were between 470 and $790 \mu \mathrm{mhos} / \mathrm{cm}$ in [18], 200 and $570 \mu \mathrm{S} / \mathrm{cm}$ in [19], 480 and $590 \mu \mathrm{S} / \mathrm{cm}$ in [20], 450 and $1064 \mu \mathrm{mhos} / \mathrm{cm}$ in [16], 414 and $808 \mu \mathrm{S} / \mathrm{cm}$ in [17], 421 and $514 \mu \mathrm{S} / \mathrm{cm}$ in [25], and 525 and $536 \mu \mathrm{S} / \mathrm{cm}$ in [26]. According to Turkish and EU drinking water standards $[8,9,11]$, it is first class. According to Turkish irrigation water standards [10], Bulakbaşı stream water is second class. Bulakbaşı stream is in the middle class salty water for irrigation, and any measures taken to prevent the accumulation of salts in the soil can be in quality that can be given to any kind of soil and plant [28].

The values of analysis with titrimetric method were given in Table 2.

There is no gaseous chlorine in natural waters, in the form of chloride or salt. Chlorine will damage the gills of aquatic animals and lead to death. A healthy drinking water is one of the important indicators [12]. It may be an indicator of sewage mixture and taste threshold value is between 250 and $500 \mathrm{mg} / \mathrm{L}$. However, up to $1500 \mathrm{mg} / \mathrm{L}$ of concentration has been found to be harmless to health. $250 \mathrm{mg} / \mathrm{L}$ of high concentrations of salts generates a bitter taste [11]. It is the highest toxic effect wherein the anion and its content are above a certain value of irrigation water, which causes leaf blight in plants. The $100-200 \mathrm{mg} / \mathrm{L}$ of sodium chloride can damage some vegetables [28]. The average chloride in the Bulakbaşı stream was determined as $84.0 \mathrm{mg} / \mathrm{L}$. Chloride values in [18] as $42-52 \mathrm{mg} / \mathrm{L}$, in [20] as $74.3-205.8 \mathrm{mg} / \mathrm{L}$, in [22] as $192.1 \mathrm{mg} / \mathrm{L}$, in [2] as $15-45 \mathrm{mg} / \mathrm{L}$, in [16] as $27.29-70.29 \mathrm{mg} / \mathrm{L}$, in [24] as 176-254 mg/L, in [17] as 23.66$94.66 \mathrm{mg} / \mathrm{L}$, in [25] as $18.1-25.3 \mathrm{mg} / \mathrm{L}$, and in [26] as $14.5-$ $16.75 \mathrm{mg} / \mathrm{L}$ have been reported. In terms of chloride values, Bulakbaşı is first-class water according to $[8,9,11]$.

In total hardness $\mathrm{Ca}$ and $\mathrm{Mg}$ are the most important two elements. They are important for skeleton structure of both aquatic and terrestrial organisms. Also, $\mathrm{Mg}$ has an important function in the blood of the human and animals. Water hardness is very important quality criteria for fisheries and drinking [12]. Generally, the total hardness is a function of the geology of the area with which the surface water is associated. Hardness has no known adverse influences on health; nevertheless, some evidence has been given to point out its impact on heart diseases [1]. A high amount of $\mathrm{Ca}$ poses no hazards to human health, but in some cases $\mathrm{Mg}$ may cause damage to the eyes. Diarrhea is another complication which might occur in these cases when they are exposed to improper amounts of $\mathrm{Mg}$. Similarly, higher amounts of $\mathrm{Ca}$ and hardness may cause a problem in terms of flavor inside the water. Also, due to the nature of the stone hot water facility will not be prompted. If the hardness is low, it leads to abrasive action [13]. Although there may be health benefits in terms of hardness, this may cause disadvantages such as more energy to be spent on increasing the soap consumption, and heating systems are also available [11]. Further, $\mathrm{Ca}$ in the irrigation water, enough to settle the matter in extreme cases, soil, and plants, leads to chlorosis and restricts the acquisition of certain nutrients. Small amount of $\mathrm{Mg}$ is sufficient for plant. Irrigation water at $24 \mathrm{mg} / \mathrm{L}$ concentration is allowed [28]. High temperature, evaporation of water, weathering of rocks, and addition of calcium and magnesium salts by means of plants and living organism are contributing factors for the hardness of the water [26]. The values of $\mathrm{Ca}, \mathrm{Mg}$, and total hardness were determined as $57.29 \mathrm{mg} / \mathrm{L}, 59.57 \mathrm{mg} / \mathrm{L}$, and $391 \mathrm{mg} / \mathrm{L}$ as $\mathrm{CaCO}_{3}$, respectively, in this study. In fisheries, $400 \mathrm{mg} / \mathrm{L}$ calcium and hardness values are accepted as suitable [14]. Bulakbaşı stream may be included in the class of very hard waters. Total hardness was reported between 155 and $220 \mathrm{mg} / \mathrm{L}$ in [18], 188 and $310 \mathrm{mg} / \mathrm{L}$ in [15], 154 and $240 \mathrm{mg} / \mathrm{L}$ in [20], 184 and $211 \mathrm{mg} / \mathrm{L}$ in [25], and 241.5 and $250.0 \mathrm{mg} / \mathrm{L}$ in [26] and averages as $474.9 \mathrm{mg} / \mathrm{L}$ in [16] and as $536 \mathrm{mg} / \mathrm{L}$ in [17].

Bicarbonate was determined as $365.94 \mathrm{mg} / \mathrm{L}$, but carbonate has not been observed in this study. Total alkalinity was determined as $299.84 \mathrm{mg} / \mathrm{L}$. Alkalinity is important in terms of impact on the buffering capacity of the water. Bulakbaşı may be included in the highly alkaline class water. In terms of value for rainbow trout farming are in the upper limit $[11,12$, 14]. Very small amount of carbonate is sufficient for plants. High concentrations of carbonate have toxic effects. It also negatively affects the physical properties of the soil. It reduces 
soil permeability. If the soil dries, it hardens and binds the duff layer. Soil large cracks are formed [28]. The total alkalinity value in [18] as $201-230 \mathrm{mg} / \mathrm{L}$, in [21] as $47.5-250.0 \mathrm{mg} / \mathrm{L}$, in [16] as $200-440.0 \mathrm{mg} / \mathrm{L}$, in [17] as $262.5-75.0 \mathrm{mg} / \mathrm{L}$, in [25] as $91-197 \mathrm{mg} / \mathrm{L}$, and in [26] as $142.0-253.5 \mathrm{mg} / \mathrm{L} \mathrm{CaCO}_{3}$ was reported.

The values of analysis with spectrophotometric method were given in Table 3.

As is known, high levels of sulfates in water can be stem from volcanic contaminations [12]. Bulakbaşı is within the geographical domains of Mount Ararat. Sulfates are major pollutants due to taste, smell, toxicity, and corrosions that they form as a result of various reactions. Sodium sulfate and magnesium sulfate, which show laxative effects in humans at $250 \mathrm{mg} / \mathrm{L}$, are limited to the upper limit. For animals the limit is of $1000 \mathrm{mg} / \mathrm{L}$. Sulfate converts into $\mathrm{H}_{2} \mathrm{~S}$ which is toxic and malodorous and formation of anaerobic conditions and bacteria activities. The value of corrosive effect of sulfate begins from 100-250 mg/L [13]. According to Turkish and EU standards [8-11], it is first class. The value of sulfate in Bulakbaşı was determined as $57.12 \mathrm{mg} / \mathrm{L}$. It was reported in [18] as $29.2-40.32 \mathrm{mg} / \mathrm{L}$, in [20] as $63.3-94.3 \mathrm{mg} / \mathrm{L}$, in [21] as $609.6-740.9 \mathrm{mg} / \mathrm{L}$, in [22] as $61.5 \mathrm{mg} / \mathrm{L}$, and in [1] as $1.67-$ $61.0 \mathrm{mg} / \mathrm{L}$.

Potassium creates much bitter taste problems in drinking water. Sources of potassium create industrial pollution, agricultural fertilizers, and soil structure. It is one of the basic nutrients desirably present in irrigation water [28]. The value of Bulakbaşı was found as $4.52 \mathrm{mg} / \mathrm{L}$. It was declared in [24] as $6.2-16.2 \mathrm{mg} / \mathrm{L}$ and in [26] as $10.27-14.57 \mathrm{mg} / \mathrm{L}$. According to Turkish, WHO, and EU standards [8-11], it is first class.

Nitrate is the final product resulting from oxidation process by nitrogenous compounds. Through nitrification process higher nitrate levels affect water quality in a negative way. Nitrate may cause blood poisoning called the blue baby disease in the stomach of the infants younger than six months and may lead to death. Nitrate, in natural waters, soil, surface, and groundwater or discharged into water by means of domestic, agricultural and industrial waste, passes through the water; an excessive amount of nitrate in water allows the proliferation of algae and aquatic plants. The amount of nitrate nitrogen in water less than $40 \mathrm{mg} / \mathrm{L}$ is desirable [12]. In Bulakbaşı stream value was found as $4.7 \mathrm{mg} / \mathrm{L}$. In other studies, it was declared to be $9.15-15.8 \mathrm{mg} / \mathrm{L}$ in [20], $54.1 \mathrm{mg} / \mathrm{L}$ in [22], maximum $3.39 \mathrm{mg} / \mathrm{L}$ in [29], maximum $0.05 \mathrm{mg} / \mathrm{L}$ in [24], and $4.23-8.53 \mathrm{mg} / \mathrm{L}$ in [1]. In Turkish, EU, WHO, Germany, and USA drinking and fisheries standards, the water is first class $[8-11,14]$. It is necessarily due to take place between irrigation waters among the essential ingredients of plant nutrients [28].

Nitrite is converted to nitrate oxidized intermediates in suitable conditions. Therefore, they are not long lasting in the natural waters. Presence in drinking water is definitely not required. They are toxic to aquatic organisms. There are toxic effects more than $100 \mu \mathrm{g} / \mathrm{L}$ in soft water and $200 \mu \mathrm{g} / \mathrm{L}$ in hard water for rainbow trout. Nitrite arises in water which has low oxygen and more organic matter problems $[12,14]$. The nitrite value in our sample was determined as $25 \mu \mathrm{g} / \mathrm{L}$. The maximum values were reported by Duran et al. [20] as $680 \mu \mathrm{g} / \mathrm{L}$ and Begum and Harikrishnarai [24] as $10 \mu \mathrm{g} / \mathrm{L}$. Since there is no oxygen deficit in Bulakbaşı stream, nitritebased pollution is not considered to be a hazard. According to $[8,9], \mathrm{WHO}$, and EU drinking water standards Bulakbaşı stream is first-class water [11].

Ammonia in water is a result of physical and chemical events or microorganism activities and because of organicbased, it is dangerous. Ammonia in water appears in two forms, ammonia $\left(\mathrm{NH}_{3}\right)$ and ammonium $\left(\mathrm{NH}_{4}\right) . \mathrm{NH}_{3}$ is toxic to all living organisms. It leads to impairments in taste and causes smelling problems. The presence of ammonia in water indicates that there is an infiltration of domestic waste water. If the ammonia is more than $50 \mu \mathrm{g} / \mathrm{L}$ in water, it has been shown to be a sign of pollution [12,13]. In Bulakbaşı stream, an average of $40 \mu \mathrm{g} / \mathrm{L}$ ammonia and $50 \mu \mathrm{g} / \mathrm{L}$ ammonium was determined. In the salmonids farming, ammonia $12.5 \mu \mathrm{g} / \mathrm{L}$ and ammonium $1000 \mu \mathrm{g} / \mathrm{L}$ cannot be required to be more [14]. Above $31 \mu \mathrm{g} / \mathrm{L}$ of ammonia is not recommended for salmonids by EU fisheries directive. According to $[8,9,11]$, Bulakbaşı stream is first-class water.

Phosphorus has a role in the energy transfer and the presence of nucleic acid is required for biological activity. Food is one of the elements that are needed for aquatic algae as well as for macrophytes growth and proliferation. Water should be available in certain concentrations of phosphorus. If there is an excessive amount, it is based on pollution. In fertilizers, foods and detergents present in excess. It is carried to water sources via runoff, irrigation, drainage, and domestic waste water leaked into the groundwater [12]. In Bulakbaşı stream the values were determined to be $80 \mu \mathrm{g} / \mathrm{L}$ as total $\mathrm{P}$, $230 \mu \mathrm{g} / \mathrm{L}$ as $\mathrm{PO}_{4}$, and $170 \mu \mathrm{g} / \mathrm{L}$ as $\mathrm{P}_{2} \mathrm{O}_{5}$. It was declared in [20] as $190-3860 \mu \mathrm{g} / \mathrm{L} \mathrm{PO}_{4}$, in [29] as $20-340 \mu \mathrm{g} / \mathrm{L} \mathrm{TP}$, in [1] as $80-1900 \mu \mathrm{g} / \mathrm{L}_{4}$, and in [26] as $123-143 \mu \mathrm{g} / \mathrm{L} \mathrm{PO}_{4}$. Total phosphorus level in drinking water is recommended as maximum $400 \mu \mathrm{g} / \mathrm{L}$ [4] and according to [9] this may be into the first quality class. EU directive designates first-class water at $400 \mu \mathrm{g} / \mathrm{L}$ of $\mathrm{P}_{2} \mathrm{O}_{5}$; in salmonids farming it is permitted in $65 \mu \mathrm{g} / \mathrm{L}[11]$.

The presence of excessive iron in water gives a metallic taste to the water. Water makes variegation. Iron do not pose any problem in terms of health but may pose some risks to laundry, textile industry, soap and toothpaste, and paper industry used in the manufacture of products; such water is not desirable due to the presence of iron stain [13]. Total iron in Bulakbaşı stream was determined as $10 \mu \mathrm{g} / \mathrm{L}$. Iron value was declared in [20] as 37.6-99.16 $\mu \mathrm{g} / \mathrm{L}$, in [21] as 221$1326 \mu \mathrm{g} / \mathrm{L}$, in [24] as $560-5200 \mu \mathrm{g} / \mathrm{L}$, and in [26] as 680$700 \mu \mathrm{g} / \mathrm{L}$. For drinking water, according to [4, 8-10], EU, US, and WHO, it can be incorporated into the first quality class [11]. In salmonids, it is permitted up to $500 \mu \mathrm{g} / \mathrm{L}$ [14].

The presence of zinc is required in waters, because it is of vital importance for skin and hair cells [13]. The average value of zinc in Bulakbaşı was found to be $169 \mu \mathrm{g} / \mathrm{L}$. The value was reported in [20] as $0.36-0.72 \mu \mathrm{g} / \mathrm{L}$, in [29] as 70$440 \mu \mathrm{g} / \mathrm{L}$, and in [26] as $40-60 \mu \mathrm{g} / \mathrm{L}$. First-class value for zinc in drinking water is $100 \mu \mathrm{g} / \mathrm{L}$; the allowable upper limit is of $5000 \mu \mathrm{g} / \mathrm{L}$ [4]. EU drinking water directive in first-class water $500 \mu \mathrm{g} / \mathrm{L}$, the WHO directive $3000 \mu \mathrm{g} / \mathrm{L}$, and the EU directive for salmonids $10-125 \mu \mathrm{g} / \mathrm{L}$ have been reported [11]. 


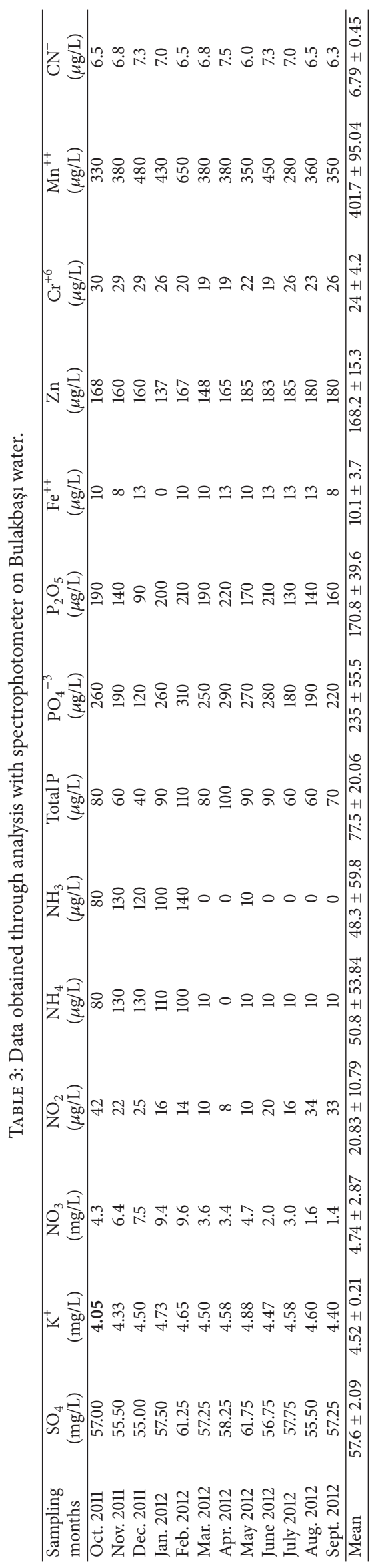


In waters, chromium is available as +3 and +6 valence chromium. $\mathrm{Cr}^{+6}$ salts are carcinogenic properties. Therefore, drinking water should be protected from chromium contamination [30]. Chromium is allergic to the skin of human [13]. $\mathrm{Cr}^{+6}$ in Bulakbaşı stream was determined as $24 \mu \mathrm{g} / \mathrm{L}$ and reported in [21] as $120 \mu \mathrm{g} / \mathrm{L}$ and in [24] as 100$120 \mu \mathrm{g} / \mathrm{L}$. According to TS 266 [8], WHCR [9] and WHO [11] chromium can be maximum $50 \mu \mathrm{g} / \mathrm{L}$ In drinking waters and, in salmonids fisheries, it can be maximum 5-50 $\mu \mathrm{g} / \mathrm{L}$ [11]. Considering the values obtained in the study results, average value is within the limit for chromium and it is the first quality class.

More than $500 \mu \mathrm{g} / \mathrm{L}$ of manganese gives a metallic taste to the water. It is a basic element in the lives of humans and animals. A certain amount of it is recommended for human beings in the drinking water to improve cardiac health and reduce cardiovascular disease mortality [30]. In this study the average value was determined as $400 \mu \mathrm{g} / \mathrm{L}$. According to $[8,9], \mathrm{WHO}$, and the EU drinking water standards [11], Bulakbaşı stream is second class.

In the nervous system and thyroid gland, cyanide causes significant problems. It is one of the most well-known poisons which is extremely dangerous to all organisms. Some fruits kernels (such as apricot and peach kernel) contain cyanide $[13,31]$. Cyanide value in the study was determined as $6.8 \mu \mathrm{g} / \mathrm{L}$. According to [8-10], EU, and WHO, it is first-class [11].

Aluminum in water is present dissolved salt, colloidal, or insoluble compounds. It constitutes strong complex ions with organic materials sulfate and fluoride [30]. When there is an excess of it, water has a discoloring property and gives turbid bluish image [13]. Aluminum could not be found in Bulakbaşı stream.

Copper causes the water taste problems and can lead to liver and kidney damage and accelerates the corrosion of other metals. Copper is originated from plating industry waste; copper sulfate is scattered the reservoirs in case of fight program with algae and pesticides. However, $1 \%$ remains in biologically available ions and passes to the remainder precipitates and sediments $[13,30]$. Copper was not detected throughout the study in our sample.

\section{Conclusion}

When Bulakbaşı stream is classified in terms of drinking, in respect to water, temperature, DO, OS, EC, $\mathrm{pH}$, chloride, calcium, hardness, nitrate, nitrite, ammonia, sulfate, phosphorus, potassium, copper, aluminum, total iron, zinc, chromium, and cyanide, it can be first-class, and with regard to magnesium, it may be first and second class, and the manganese can be second quality class. In terms of fisheries, $\mathrm{P}_{2} \mathrm{O}_{5}$ and alkalinity are only slightly above the first quality class. Bulakbaşı stream has the first quality in terms of other parameters. With respect to analysis and measurement of all parameters, it is suitable quality of water for both salmonids and other species. In point of irrigation, it is considered as second quality class with respect to EC, magnesium, and alkalinity and first-class in terms of other parameters. Irrigation water is a quality that can be used easily.
In terms of quality and clean drinking water in our world in an age in which there is an increasing impoverishment, it is of paramount importance to protect natural resources, which must be well managed and kept clean. We should also implement due measures for the protection and rehabilitation of the available resources.

When taking into consideration research findings related with water quality classes described above, it would be much more tempting to say that Bulakbaşı in Iğdır as a drinking water supply for the surrounding settlements can be considered to possess features that are suitable for potable water and favorable for trout and carp farming. However, in order to determine the carrying capacity of water to be used, and taking into account the results obtained from this study, we should provide a good resource for management planning.

\section{Disclosure}

This study was produced from the data of Master Thesis conducted by Abdullah AKSOY in the management of Associate Professor Dr. Fazıl ŞEN.

\section{Conflict of Interests}

The authors declare that there is no conflict of interests regarding the publication of this paper.

\section{References}

[1] F. Al-Badaii, M. Shuhaimi-Othman, and M. B. Gasim, "Water quality assessment of the Semenyih river, Selangor, Malaysia," Journal of Chemistry, vol. 2013, Article ID 871056, 10 pages, 2013.

[2] S. Dirican and M. Barlas, "Physico-chemical characteristics and fish of Dipsiz and Çine (Muğla-Aydın) stream," Ekoloji, vol. 14, no. 54, pp. 25-30, 2005.

[3] O. Çetinkaya, M. Sarı, F. Şen, M. Arabacı, and H. A. Duyar, "Limnological characteristics of Karasu river inflowing lake van,” Yuzuncu Yil University Agricultural Sciences, vol. 4, pp. 151$168,1994$.

[4] A. Türkman, S. Tokgöz, and H. Sarptaş, "Drinking water standards and reliable drinking water," in Proceedings of the $3 \mathrm{rd}$ National Congress on Environmental Engineering, pp. 1-9, İzmir, Turkey, November 1999.

[5] Anonymous, "General Geography of Igdir," 2014, http://www .igdir.gov.tr/default_B0.aspx?content=219.

[6] A. E. Greenberg, L. S. Clesceri, and A. D. Eaton, Standard Methods for the Examination of Water and Wastewater, APHA, AWWA, WEF, Washington, DC, USA, 1992.

[7] Hach, DR 5000 Spectrophotometer Working Procedures, HachLange-DOC022.52.00667, Hach Lange, Düsseldorf, Germany, 2005.

[8] TS 266, "Water intended for human consumption," ICS 13.060.20, Turkish Standards Institute, Ankara, Turkey, 2005.

[9] WHCR, Water Intended for Human Consumption Regulation, Turkish Official Gazette, 2005.

[10] WPCR, “Turkish water pollution control regulation," Official Gazette No. 25687, Turkish Official Gazette, 2004.

[11] T. H. Y. Tebbutt, Principles of Water Quality Control, chapter 2, Butterworth-Heinemann Elsevier, Oxford, UK, 5th edition, 1998. 
[12] O. Çetinkaya, Water Quality, Yüzüncü Yıl University, Agricultural Faculty, Van, Turkey, 2003.

[13] "The Measurements of The Parameters in Drinking Water," 2014, http://www.aqualine.gen.tr/icme-suyunda-olcumu-yapilan-parametreler.html.

[14] Y. Emre and V. Kürüm, Trout Breeding in Ponds and Cages, Posta Publishing, Istanbul, Turkey, 2nd edition, 2007.

[15] F. Şen, A study on population of carp (Cyprinus carpio, L. 1758) in Nazik Lake [Ph.D. thesis], Ataturk University, Erzurum, Turkey, 2001.

[16] N. Cantürk, The investigation of the water quality of the Akköprü stream inflowing to Lake Van, Turkey [M.S. thesis], Yüzüncü Yıl University, Van, Turkey, 2007.

[17] I. Şekerci, The investigation of the water quality of Karasu (Mermit) stream inflowing to Lake Van, Turkey [M.S. thesis], Yüzüncü Yıl University, Van, Turkey, 2011.

[18] S. V. Agarkar, "Assessment of water quality of Sakegaon reservoir, Maharashtra," Asian Journal of Chemistry, vol. 10, no. 4, pp. 997-998, 1998.

[19] N. Kazanci and M. Dügel, "An evaluation of the water quality of Yuvarlakçay stream, in the Köycegiz-Dalyan protected area, SW Turkey," Turkish Journal of Zoology, vol. 24, no. 1, pp. 69-80, 2000.

[20] M. Duran, M. Tüzen, and M. Kayim, "Exploration of biological richness and water quality of stream Kelkit, Tokat-Turkey," Fresenius Environmental Bulletin, vol. 12, no. 4, pp. 368-375, 2003.

[21] P. M. Gopalswami, P. E. Kumar, and A. R. Kulandaivelu, "Study on the quality of water in the Bhavani river," Asian Journal of Chemistry, vol. 15, no. 1, pp. 306-310, 2003.

[22] Y. A. Maruthi and S. R. Rao, "Physico-chemical, biological and bacteriological study of Sarada river," Asian Journal of Chemistry, vol. 16, no. 1, pp. 122-130, 2004.

[23] R. L. Thomas, J. C. Cadham, S. Hassan et al., "A physicochemical characterization of the waters of the El-Kabir River and major tributaries in Syria and Lebanon," Lakes \& Reservoirs: Research and Management, vol. 10, no. 2, pp. 103-108, 2005.

[24] A. Begum and Harikrishnarai, "Study on the quality of water in some streams of cauvery river," E-Journal of Chemistry, vol. 5, no. 2, pp. 377-384, 2008.

[25] A. Kumar and Y. Bahadur, "Water quality of river kosi and rajera system at Rampur (India): impact assessment," Journal of Chemistry, vol. 2013, Article ID 618612, 4 pages, 2013.

[26] M. Sharma, "Water quality assessment of the Central Himalayan Lake, Nainital," Advances in Environmental Chemistry, vol. 2014, Article ID 473074, 5 pages, 2014.

[27] B. Ödemiş, M. K. Sangün, and D. Büyüktaş, "Temporal variations in water quantity and quality of Orontes River, Turkey," Asian Journal of Chemistry, vol. 19, no. 1, pp. 711-723, 2007.

[28] A. Günay, General and Special Vegetables: Irrigation Water Quality, 2014, http://www.bahcesel.net/forumsel/genel-ve-ozel-sebzecilik-profdratila-gunay/16995-sulama-suyunun-ozelliklerisulama-sebzecilik/.

[29] F. Tanir, Z. Sütoluk, M. Z. L. Göksu, and M. Akbaba, "An investigation on chemical and bacteriological quality of Seyhan river water in the Province of Adana, Turkey," Asian Journal of Chemistry, vol. 17, no. 4, pp. 2720-2726, 2005.

[30] C. Güler and Z. Çobanoğlu, Water Quality, Ministry of Health of Turkey, General Directorate of Primary Health Care Publications, Ankara, Turkey, 1997.
[31] M. Özdemir and B. Sirıken, "Determination of cyanide levels in well water in the Afyonkarahisar region," Veterinary Journal of Ankara University, vol. 53, no. 1, pp. 37-40, 2006. 

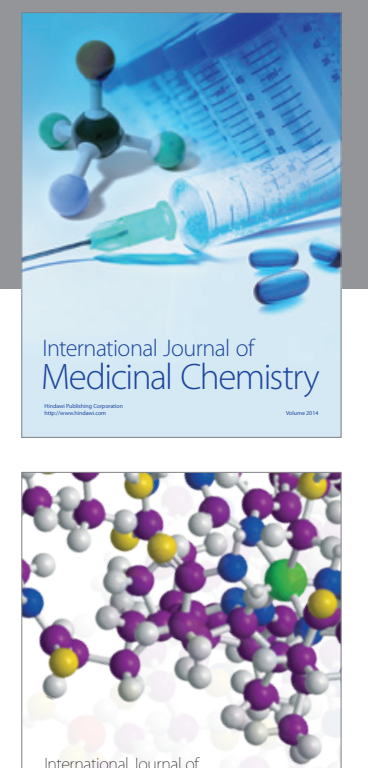

\section{Carbohydrate} Chemistry

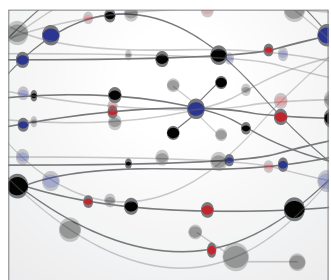

The Scientific World Journal
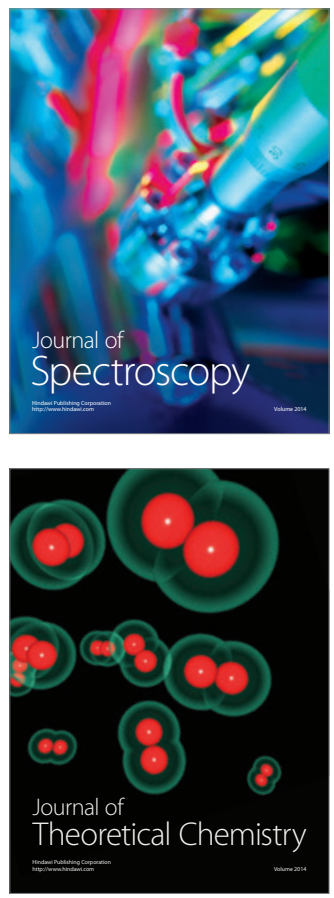
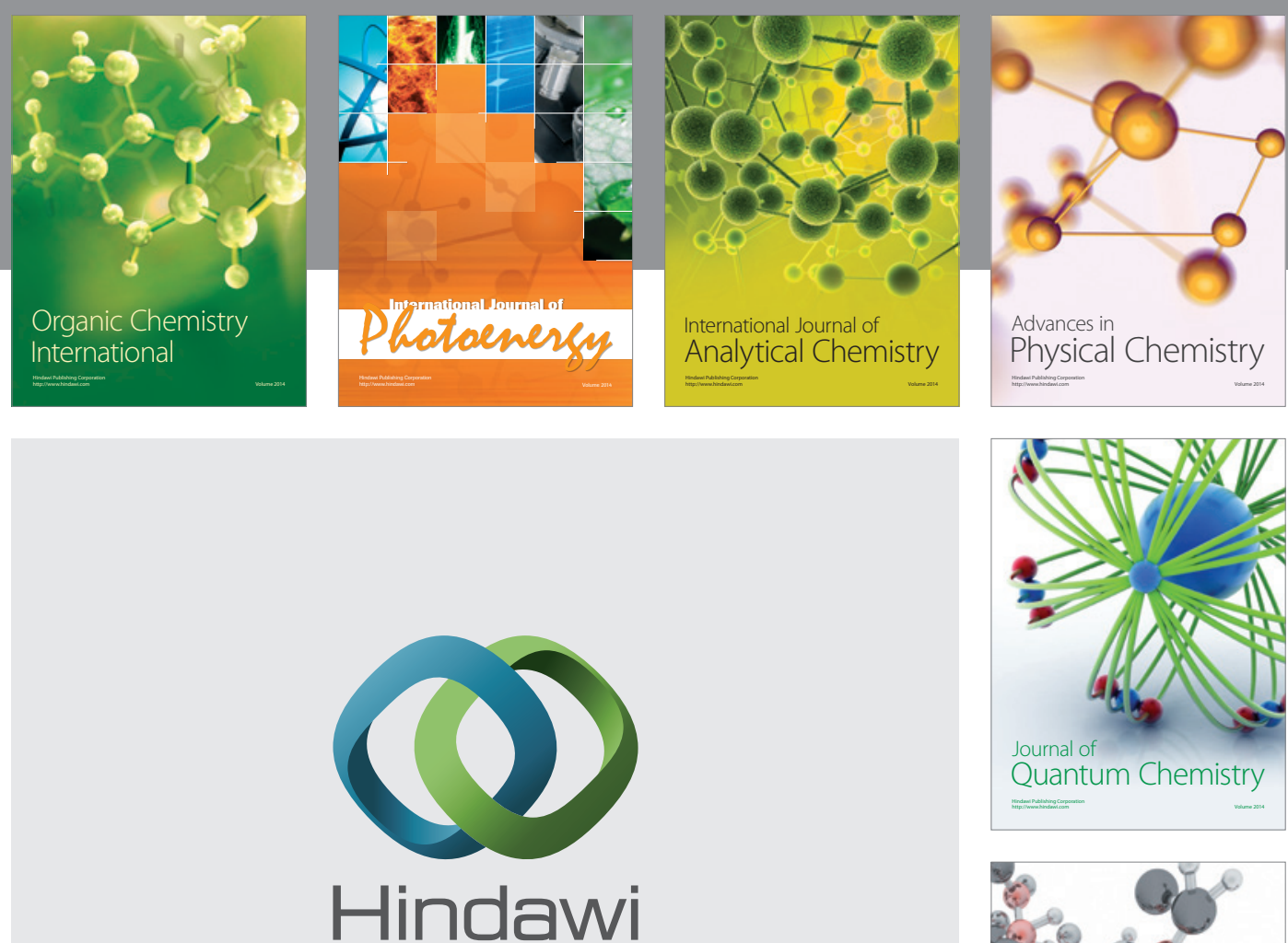

Submit your manuscripts at

http://www.hindawi.com

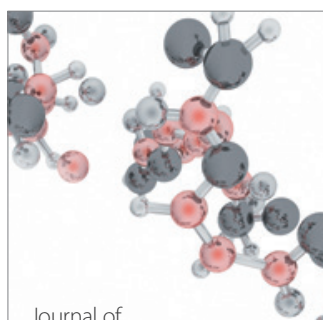

Analytical Methods

in Chemistry

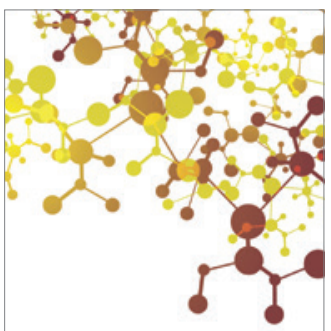

Journal of

Applied Chemistry

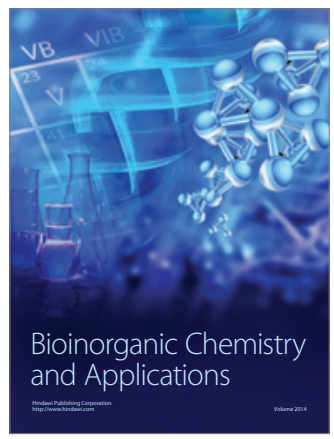

Inorganic Chemistry
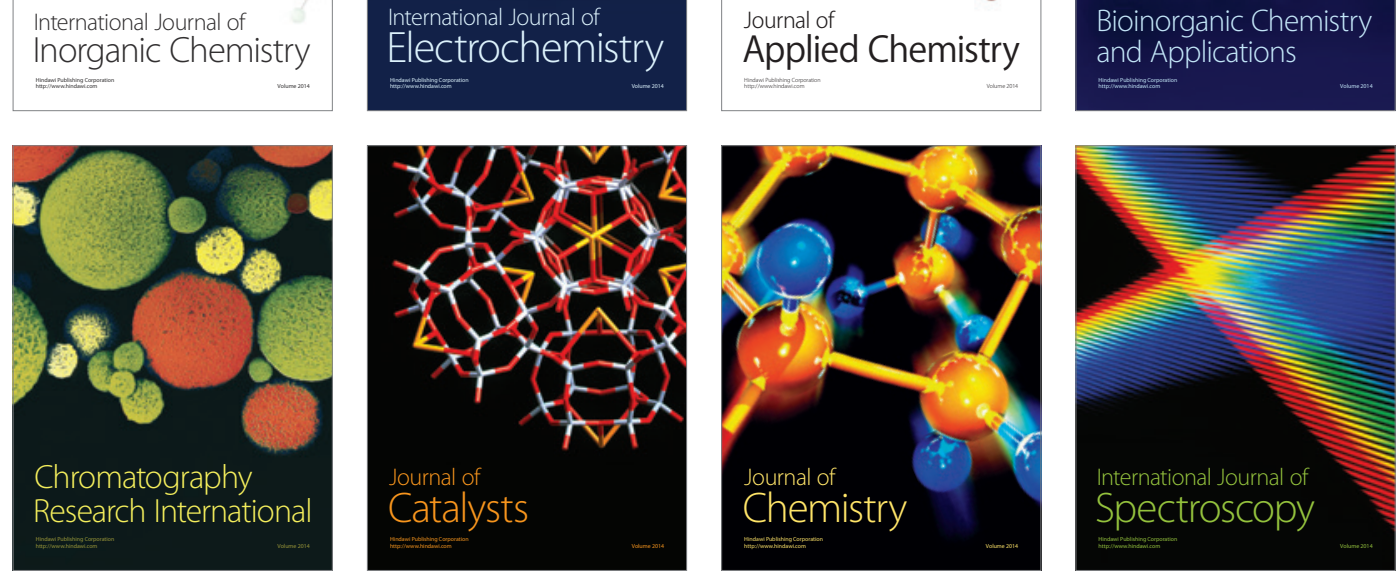